\title{
Fluorescent dissolved organic matter in the continental shelf waters of western Bay of Bengal
}

\author{
N V H K Chari, P Sudarsana Rao and Nittala S Sarma* \\ Marine Chemistry Laboratory, School of Chemistry, Andhra University, Visakhapatnam 530 003, India. \\ ${ }^{*}$ Corresponding author. e-mail: nssarma@rediffmail.com
}

Fluorescent dissolved organic matter (FDOM) of southwestern Bay of Bengal surface water during southwest monsoon consisted five fluorophores, three humic-like and two protein-like. The humification index (HIX) and humic fluorophores, viz., visible (C), marine (M) and UV (A) humic-likes indicated, better than biogeochemical constituents analyzed, that the northern-half region of the study area which is closer to the head bay (less salinity) is distinctly more terrestrially influenced. Similarly, the southernhalf region (less dissolved oxygen) is indicated as more in situ influenced. This region is enriched with tyrosine protein-like fluorophore (B), an indicator of bacterial metabolism in some of its samples due to upwelled water. Although chlorophyll $a$ is less in this (southern) region, the fluorescence based biological index (BIX) which is an index of recent phytoplankton production is about the same in the two regions, and the lower chlorophyll $a$ of southern region is attributed to greater grazing pressure. Fluorescence properties, e.g., BIX are more informative about phytoplankton production than chlorophyll $a$.

\section{Introduction}

The dissolved organic matter (DOM) of the hydrosphere is characterized up to ca. $4-11 \%$ as discrete compounds, e.g., carbohydrates, amino acids, hydrocarbons, phenolic acids, etc. The remaining major fraction is uncharacterised at the molecular level. This complex organic matter comprises humic substances, fulvic acids and other polymeric organic matter (Benner 2002). This major fraction of DOM has been a subject of characterization by optical methods, e.g., absorption and fluorescence. The fraction exhibiting strong absorption of short wavelength (ultraviolet to blue) radiation, is termed as chromophoric dissolved organic matter (CDOM) (Coble 2007). A small fraction of CDOM, ca. $5 \%$ that emits fluorescence when irradiated by ultraviolet light (Kalle 1949) is the fluorescent DOM (FDOM). Major sources for FDOM of the coastal water include both external sources (rivers, groundwater, and anthropogenic inputs) and in situ sources (biologically produced and transformed) (Hansell and Carlson 2002; Coble 2007). FDOM has been traditionally used as tracer of different source waters. Recent developments in the identification and quantification of different fluorophores have increased the potential of FDOM to more applications, e.g., phytoplankton bloom monitoring, pollution studies, etc. (Hudson et al. 2007).

The measurement of FDOM requires small sample volumes and does not involve cumbersome isolation and purification steps. Prior studies on FDOM confined to single excitation (ex), emission (em) wavelength combination, i.e., $350 \mathrm{~nm}(\mathrm{ex}) / 450 \mathrm{~nm}$ (em), e.g., in the Bay of Bengal (Sarma et al. 1994). Since the early nineties, three dimensional excitation emission matrix (EEM) spectra are used increasingly for the characterization of

Keywords. Fluorescent dissolved organic matter (FDOM); excitation emission matrix spectra; PARAFAC analysis; humification index (HIX); biological index (BIX); Bay of Bengal. 
Table 1. Fluorophore groups' identification.

\begin{tabular}{|c|c|c|c|c|c|c|}
\hline \multirow[b]{2}{*}{ Peak } & \multicolumn{2}{|c|}{ This study } & \multicolumn{2}{|c|}{ Coble (1996) } & \multirow[b]{2}{*}{ Characterization } & \multirow[b]{2}{*}{ Source } \\
\hline & $\begin{array}{c}\mathrm{Ex}_{\max } \\
(\mathrm{nm})\end{array}$ & $\begin{array}{l}\mathrm{Em}_{\max } \\
(\mathrm{nm})\end{array}$ & $\begin{array}{c}\mathrm{Ex}_{\max } \\
(\mathrm{nm})\end{array}$ & $\begin{array}{l}\mathrm{Em}_{\max } \\
(\mathrm{nm})\end{array}$ & & \\
\hline $\mathrm{A}$ & 250 & $415-435$ & 280 & $380-460$ & UV humic-like & Terrigenous (natural) \\
\hline $\mathrm{T}$ & 280 & 330 & 275 & 340 & Tryptophan protein-like & $\begin{array}{l}\text { Marine and terrigenous } \\
\text { (biological) }\end{array}$ \\
\hline M & 290 & 405 & 312 & $380-420$ & Humic-like & Marine \\
\hline B & 270 & 295 & 275 & 310 & Tyrosine protein-like & $\begin{array}{l}\text { Marine and terrigenous } \\
\text { (biological degradation) }\end{array}$ \\
\hline $\mathrm{C}$ & 365 & 455 & 350 & $420-480$ & Visible humic-like & $\begin{array}{l}\text { Terrigenous } \\
\text { (anthropogenic and degraded humics) }\end{array}$ \\
\hline
\end{tabular}

FDOM (Coble et al. 1990, 1998; Coble 1996; Del Castillo et al. 1999; Mayer et al. 1999; Marhaba et al. 2000; Parlanti et al. 2000; Kowalczuk et al. 2003, 2005, 2009, 2010; Yamashita and Tanoue 2003, 2004; Guéguen et al. 2005; Hong et al. 2005). This technique, supplemented with parallel factor (PARAFAC) analysis provides information on various fluorophores that constitute FDOM. Five fluorophores (table 1) attributed to unique sources are commonly found in natural waters (Stedmon et al. 2003; Stedmon and Markager 2005; Murphy et al. 2008; Kowalczuk et al. $2009,2010)$. The distribution and concentration of individual fluorophores (A, C, M, T and B) and fluorescence-based indices, e.g., HIX are used diagnostically to draw inferences on the source of DOM, e.g., terrestrial/marine inputs, bacterial/phytoplankton sources, and processes, e.g., humification/degradation (Coble 2007).

The Bay of Bengal is a tropical semienclosed basin to the north east of the Indian Ocean and receives a large freshwater influx ca. $1600 \mathrm{~km}^{3} \mathrm{yr}^{-1}$, i.e., $\sim 50,000 \mathrm{~m}^{3} \mathrm{sec}^{-1}$ (Subramanian 1993) from the rivers draining India, Bangladesh, Nepal and Myanmar. For an oceanic surface area of $1.13 \%$, this influx constitutes $6.6 \%$ of the global river flux. The terrestrial discharges are a vector of organic matter into the Bay. The export flux of total organic carbon (DOC+POC) to the Bay of Bengal by the GangaBrahmaputra $(\mathrm{G}-\mathrm{B})$ river system at the head Bay is about $650 * 10^{9} \mathrm{molC} \mathrm{yr}^{-1}$ (Aucour et al. 2006). Compared to this, the flux from river Godavari, the largest of the Indian peninsular rivers is estimated as only $63 \times 10^{9} \mathrm{molC} \mathrm{yr}^{-1}$ (Sarin et al. 2002). Fluxes also take place from other peninsular rivers namely Mahanadi, Krishna, Cauvery and Penna, at peak level, during the monsoon season.

Due to the complex hydrographic conditions, the western Bay of Bengal is associated with highly variable bio-optical properties and there exists a large gap of studies in this area. As a part of the Satellite Coastal and Oceanographic Research (SATCORE) programme of Indian National Centre for Ocean Information Services (INCOIS), we initiated to analyse the variability of the optical characteristics of the western coastal Bay of Bengal waters. In this paper we present a detailed study of fluorescence spectroscopic properties of CDOM in the continental shelf waters of Bay of Bengal during southwest monsoon. The objective of the paper was to identify the fluorescence signature and explore different fluorophores of FDOM for identifying the oceanographic conditions.

\section{Material and methods}

\subsection{Study area}

Stations are located as shown in figure 1 along 8 transects (T1-T8) off the East Indian coast between Bhimunipatnam and Nagapattinam. The transects are nearly opposite to rivers like Godavari (T2), Krishna (T3), Palar (T7) and Cauvery (T8); else, they are off coastal cities like Visakhapatnam (T1) and Chennai (T6). The T4 and T5 transects are on either side of Penna (Penner in figure 1) estuary. The waters of the four northern transects (T1, T2, T3, T4) are under a greater influence of the southwest monsoon than the southern transects (T5, T6, T7, T8). During this season India receives heavy rainfall and this water reaches mostly the Bay of Bengal after flowing through the Himalayan $\mathrm{G}-\mathrm{B}$ river system, and peninsular rivers namely Mahanadi, Godavari, Krishna and Cauvery.

\subsection{Sampling and analytical methods}

Seawater samples were collected from standard depths using a Seabird Rosette system fitted with 12 Niskin bottles each 1.8 litre capacity and CTD onboard FORV Sagar Sampada from 1-8 


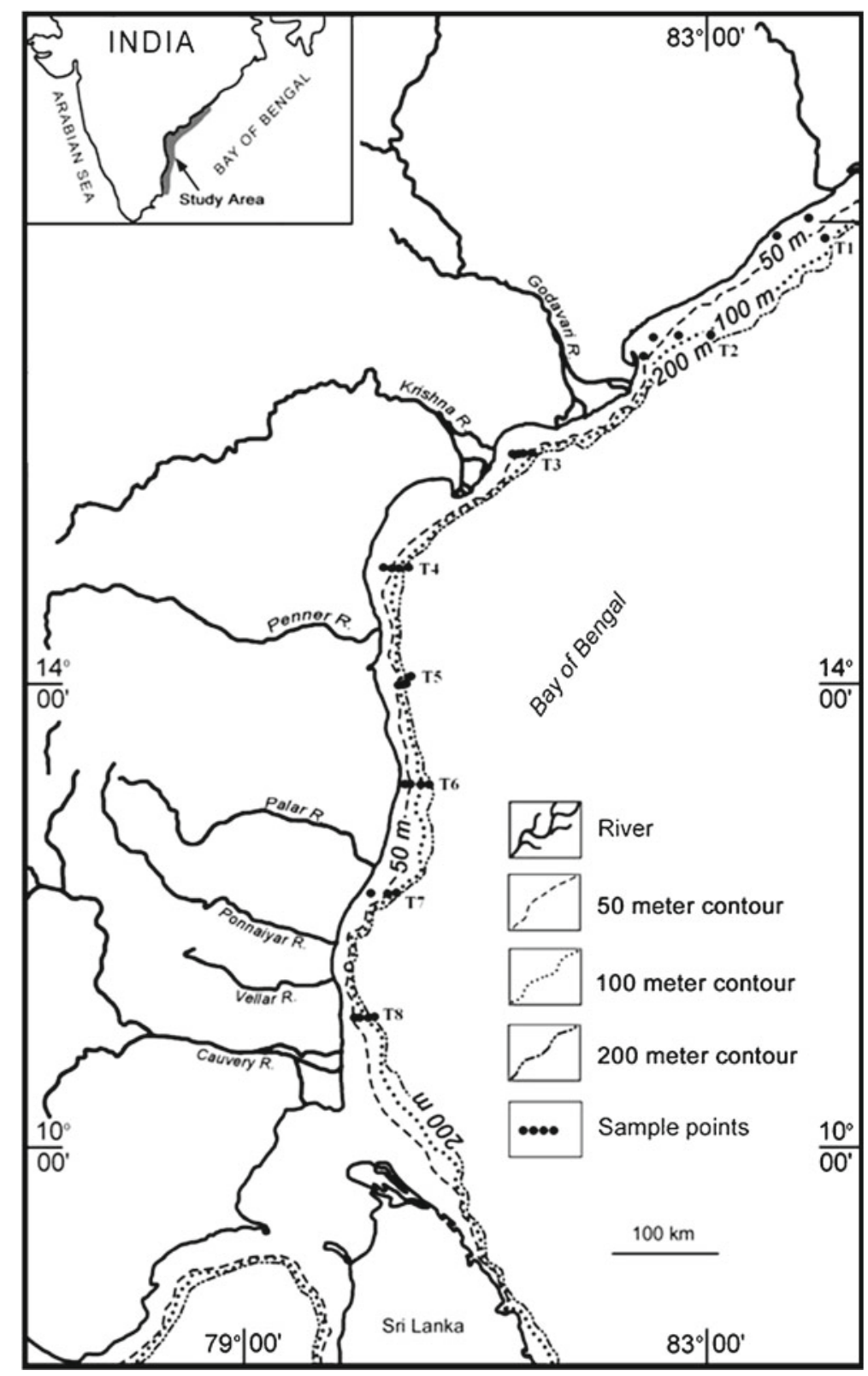

Figure 1. Study area comprising the eight transects (T1, T2, ., T8) and station locations (•) along 50,100 and 200 meters isobaths (the $30 \mathrm{~m}$ contour is not shown due to low resolution on map) $(\mathrm{R}=$ river).

September 2009 (Cruise no. 271). The CTD salinities were calibrated with on-deck analysis of discrete samples using guideline 8400 AUTOSAL (Ocean Scientific International, Petersfield, UK). We limited our analysis to surface (i.e., $1 \mathrm{~m}$ depth) samples. Samples were filtered immediately after their collection through GF/F filter papers and analysed onboard for nitrite, nitrate, phosphate and silicate by following the standard photometric procedures (Grasshoff et al. 1999) with Unicam $\alpha$ double beam spectrophotometer. Dissolved oxygen was determined using modified Winkler titration method (Carritt and Carpenter 1966). For chlorophyll $a, \mathrm{GF} / \mathrm{F}$ filters containing the particulate matter were preserved at $-20^{\circ} \mathrm{C}$ until they were extracted with $90 \%$ acetone for $24 \mathrm{hr}$ at $4^{\circ} \mathrm{C}$ and the absorbance measured by UV1800 Shimadzu double beam spectrophotometer in the Andhra University laboratory. The calculation for chlorophyll $a$ (equivalent) concentration was by Jeffrey equations (Jeffrey and Humphrey 1975), and was uncorrected for phaeopigments.

\subsection{Fluorescence measurements}

For FDOM measurements, a portion of seawater sample was filtered immediately after collection 
through $0.22 \mu$ Millipore membrane filters, prewashed by soaking for 5 minutes in MilliQ water, under dim light in amber coloured bottles. The fluorescence measurements were done for $4^{\circ} \mathrm{C}$ stored samples after equilibration to constant room temperature $\left(24 \pm 1^{\circ} \mathrm{C}\right)$ on Horiba Jobin Yvon Fluoromax-4 spectrofluorometer in the Andhra University laboratory. The spectrofluorometer was equipped with $150 \mathrm{~W}$ ozone-free xenon arclamp and R928P detector. The Excitation Emission Matrix (EEM) spectra were collected using excitation wavelengths from 250 to $400 \mathrm{~nm}$ at $5 \mathrm{~nm}$ intervals and the emission wavelengths from 290 to $550 \mathrm{~nm}$, also at $5 \mathrm{~nm}$ intervals. The instrument was set-up to collect the signal in ratio mode $(\mathrm{S} / \mathrm{R}$ ) using $5 \mathrm{~nm}$ bandwidth on both excitation and emission monochromators with integration time $0.2 \mathrm{sec}$. For most samples, the absorbance at $350 \mathrm{~nm}$ was $<0.2$ (i.e., 0.02 with $1 \mathrm{~cm}$ cuvette). A few samples (10 nos) for which the absorbance was $>0.2$ were diluted by $5 \times$ with
Milli-Q (organic free) water to remove inner filter effects (Kowalczuk et al. 2005) for recording the EEM spectrum. The EEM spectra were corrected for instrument configuration by using factory-supplied correction factors. The resultant spectra were Raman calibrated and the intensity expressed as Raman Units (RU). The RU is quantitatively independent of instrument specificities and therefore comparable to measurements from other instruments and on the same instrument at different times. Blank Milli-Q water EEM spectrum was subtracted from all samples to remove water Raman scattering effects. The contour plots of 3D EEM spectra were drawn using Matlab R2007a software.

\subsection{PARAFAC analysis}

The parallel factor (PARAFAC) analysis extracts components that represent individual fluorophores and their concentrations from the large dataset
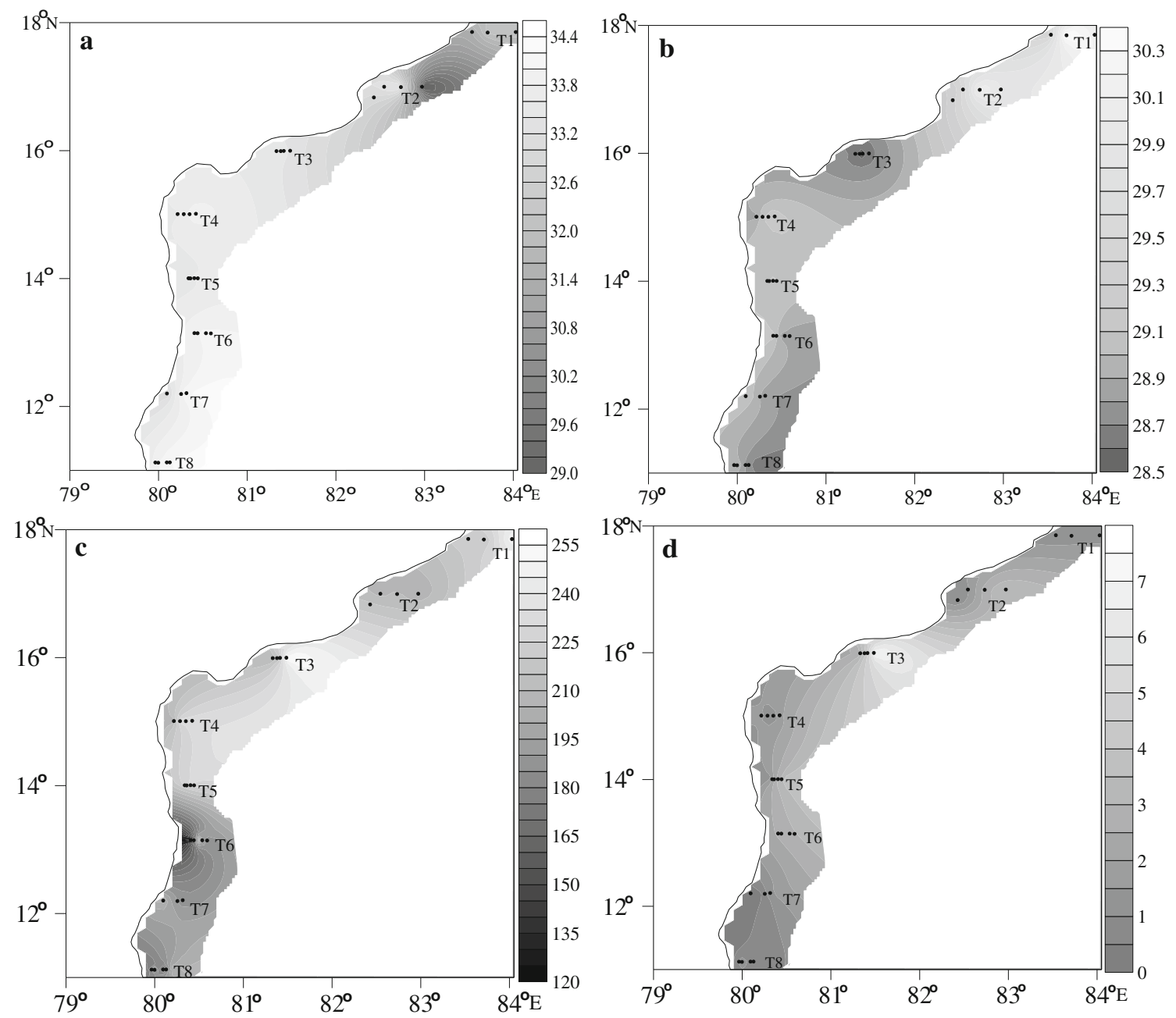

Figure 2. Contours of (a) salinity, (b) temperature $\left({ }^{\circ} \mathrm{C}\right),(\mathbf{c})$ dissolved oxygen $(\mu \mathrm{M})$, and $(\mathbf{d}) \mathrm{Chl}^{a}\left(\mathrm{mgm}^{-3}\right)$. 
Table 2. Data summary for the two regions.

\begin{tabular}{|c|c|c|c|c|c|c|c|c|}
\hline \multirow[t]{2}{*}{ Constituent* } & \multicolumn{4}{|c|}{ North (T1-T4 and T5 offshore) } & \multicolumn{4}{|c|}{ South (T6-T8 and T5 coastal) } \\
\hline & Min & Max & Av & $\mathrm{SD}$ & Min & Max & Av & $\mathrm{SD}$ \\
\hline Nitrite & 0.02 & 0.13 & 0.04 & 0.03 & 0.02 & 0.23 & 0.06 & 0.06 \\
\hline Phosphate & 0.05 & 0.36 & 0.18 & 0.09 & 0.05 & 0.36 & 0.23 & 0.11 \\
\hline Silicate & 1.43 & 6.67 & 2.81 & 1.63 & 0.06 & 3.96 & 2.21 & 1.15 \\
\hline Nitrate & 0.99 & 11.17 & 5.01 & 4.17 & 0.00 & 10.65 & 3.62 & 3.60 \\
\hline Salinity & 32.08 & 33.90 & 33.30 & 0.56 & 33.00 & 34.24 & 33.92 & 0.33 \\
\hline Temperature & 28.48 & 30.47 & 29.31 & 0.58 & 28.65 & 29.19 & 28.95 & 0.16 \\
\hline Chl $a$ equivalent & 0.48 & 7.24 & 2.37 & 1.75 & 0.15 & 3.69 & 1.38 & 1.16 \\
\hline Dissolved oxygen (DO) & 205 & 256 & 221 & 16 & 119 & 238 & 192 & 32 \\
\hline A & 0.007 & 0.096 & 0.038 & 0.031 & 0.005 & 0.060 & 0.025 & 0.019 \\
\hline M & 0.001 & 0.020 & 0.007 & 0.006 & 0.001 & 0.010 & 0.005 & 0.003 \\
\hline $\mathrm{T}$ & 0.002 & 0.045 & 0.013 & 0.013 & 0.003 & 0.035 & 0.012 & 0.010 \\
\hline $\mathrm{C}$ & 0.001 & 0.008 & 0.003 & 0.003 & 0.000 & 0.005 & 0.002 & 0.001 \\
\hline B & 0.006 & 0.057 & 0.024 & 0.018 & 0.004 & 0.069 & 0.026 & 0.021 \\
\hline $\mathrm{B} / \mathrm{M}$ & 1.793 & 8.186 & 3.995 & 1.734 & 2.942 & 8.169 & 4.479 & 1.565 \\
\hline $\mathrm{A} / \mathrm{C}$ & 11.902 & 16.426 & 13.460 & 1.447 & 13.174 & 16.490 & 14.582 & 1.137 \\
\hline HIX & 0.962 & 2.185 & 1.512 & 0.337 & 0.261 & 1.763 & 1.108 & 0.376 \\
\hline BIX & 0.697 & 1.045 & 0.850 & 0.080 & 0.837 & 1.147 & 0.912 & 0.092 \\
\hline
\end{tabular}

*Units: Nitrite, Phosphate, Silicate, Nitrate and DO ( $\mu \mathrm{M})$; Salinity (\%o); Temperature $\left({ }^{\circ} \mathrm{C}\right) ; \mathrm{A}, \mathrm{M}, \mathrm{T}, \mathrm{C}, \mathrm{B}(\mathrm{RU})$.

of 3D EEM spectra. The components are mathematically independent, and each can be considered as a chemical analyte or a group of strongly covarying analytes (Bro 1997). The PARAFAC was done in MATLAB R2007a using the DOMFluor, which contains $\mathrm{N}$ way toolbox ver 3.1 (Stedmon and Bro 2008). Before the PARAFAC analysis, high intensity EEM data attributable to the second order Rayleigh scattering were replaced with nil values (Anderson and Bro 2003). Determination of the optimum number of components was done by split half analysis and random initialisation (Stedmon and Bro 2008), as a part of the programme. The PARAFAC analysis was applied to our dataset (26 samples). The PARAFAC analysis gives the relative intensities (scores) of the components, from which the absolute intensities $(I)$ were calculated by multiplying with the corresponding excitation and emission loadings at their $\lambda_{\max }$ (Stedmon et al. 2003; Kowalczuk et al. 2009). For the $n$th component:

$$
\begin{aligned}
I_{n}= & \operatorname{Score}_{n} * \operatorname{Loading}_{n(\mathrm{ex})}\left(\lambda_{\max }\right) \\
& * \operatorname{Loading}_{n(\mathrm{em})}\left(\lambda_{\max }\right),
\end{aligned}
$$

where Score $_{n}$ is the relative intensity of the $n$th component, Loading $_{n(\mathrm{ex})}\left(\lambda_{\max }\right)$ is loading of the $n$th component at the excitation maximum, and Loading $_{n(\mathrm{em})}\left(\lambda_{\max }\right)$ is the loading of the $n$th component at the emission maximum derived from the model.
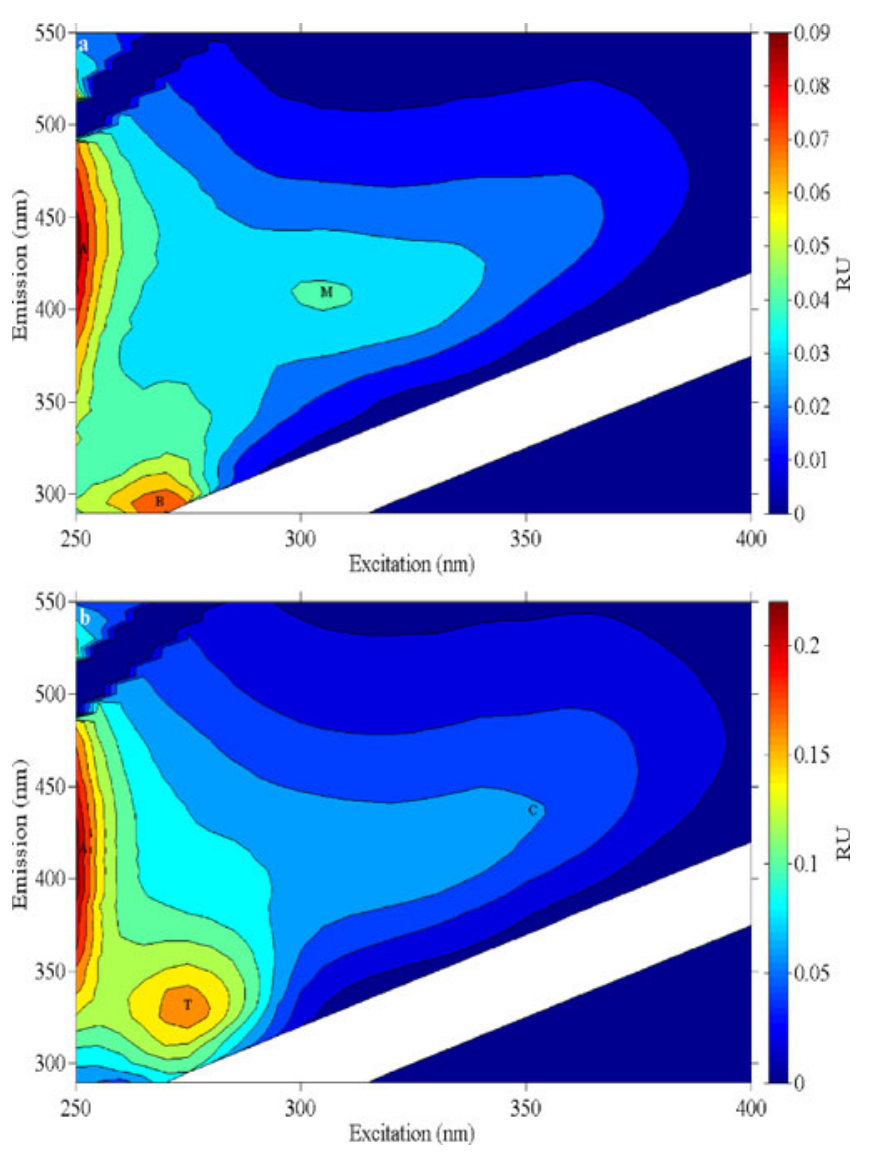

Figure 3. Examples of EEM spectra: (a) T5 transect $50 \mathrm{~m}$ isobath showing $\mathrm{A}, \mathrm{B}$ and $\mathrm{M}$ peaks, and (b) T7 transect $30 \mathrm{~m}$ isobath showing $\mathrm{A}, \mathrm{T}$ and $\mathrm{C}$ peaks. 


\section{Results}

\subsection{Hydrography and nutrients}

The weather was mostly dry with intermittent small spells of rain during the cruise. All the sampling stations were occupied during daytime (8 AM to $6 \mathrm{PM})$. At surface, salinity ranged from 28.86 to 34.24. The lowest salinity was at the station closest to the Godavari river mouth (T2, $30 \mathrm{~m}$, figure 1). The highest salinity was also at a coastal station $(\mathrm{T} 8,30 \mathrm{~m})$. In most transects, the nearshore $(30 \mathrm{~m})$ water did not show the typical dilution that must be seen when significant terrestrial fresh water input takes place during the (peak) monsoon season. Indeed, salinity decreased gently in the offshore direction. A general southward increasing salinity contours also characterize the study area (figure 2a). Temperature ranged from 28.48 to $30.47^{\circ} \mathrm{C}$ and decreased southwards (figure $2 \mathrm{~b}$ ). Dissolved oxygen (DO) concentration ranged from 119.2 to $255.8 \mu \mathrm{M}$ (table 2; figure 2c). Nutrient concentrations were in the ranges of $0.021-0.23$, $0.06-11.17,0.05-0.36$ and $0.06-6.67 \mu \mathrm{M}$ of nitrite, nitrate, phosphate and silicate, respectively. The chl $a$ equivalent values ranged from 0.15 to 7.24 $\mathrm{mgm}^{-3}$ averaging at $1.97 \mathrm{mgm}^{-3}$, with highest values observed in T3 (figure $2 \mathrm{~d}$ ). A preliminary examination indicated that the study area consists of two distinct regions - the northern region (T1-T4) and the southern region (T6-T8). In T5, the nearshore stations $(30-50 \mathrm{~m})$ were similar to the southern region and the offshore stations (100-200 m) were similar to the northern region. The mean concentrations of various parameters analyzed for the two regions (table 2) show significant differences. The northern half (T1-T4 plus T5 offshore) of the study area is associated with lower mean salinity (difference between the two regional means, $\Delta=0.87)$ and silicate $(0.96 \mu \mathrm{M})$. While an associated decrease might be expected for nitrate, this nutrient indeed showed enrichment (0.59) than the southern half (T6-T8 plus T5 nearshore) (table 2$)$. The DO is supersaturated $(+9.8 \%$ of saturation concentration) in the northern and undersaturated $(-12.8 \%)$ in the southern regions.

\subsection{Fluorescence properties}

Examples of EEM spectra are shown in figure 3. The PARAFAC analysis of EEM spectra extracted five fluorophoric components from the dataset (figure 4). The components 1-5 contain one fluorophore each namely A, M, T, C and B respectively (table 1). The mean abundance was highest for $\mathrm{A}$ and for both A and B fluorophores in the northern and southern regions, respectively. Other three fluorophores (M, T and $\mathrm{C}$ ) were minor in both regions. The $\mathrm{A}, \mathrm{M}$, and $\mathrm{C}$ flurophores were more enriched in the northern and $\mathrm{T}$ and $\mathrm{B}$ fluorophores were more enriched in the southern region (figure 5). The A fluorophore is strongly correlated positively to the other two humic fluorophores $\mathrm{M}$ $\left(R^{2}=0.97, n=29\right)$ and $\mathrm{C}(0.99,29)$ (figure 6) indicating that the three have related origins. With $\mathrm{T}$, the correlation of $\mathrm{A}$ is less significant (0.63), and with $\mathrm{B}$, there is no correlation.

\section{Discussion}

\subsection{North-south variability: hydrography}

The lower salinity of the northern waters is because during the southwest monsoon season (June-September), heavy rains in catchment areas over the Indian subcontinent cause floods in the rivers reaching the Bay. The effect of flooding of the Ganga river is far greater - the long term mean Ganga discharge during August-September is around 40,000 $\mathrm{m}^{3} \mathrm{~s}^{-1}$ (annual mean: 11,400) (Jian et al. 2009). This water from the head Bay constituting the northern component of the East India coastal current (EICC) modifies the north western Bay of Bengal surface water, the effect decreasing southwards. At the same time, a second component of the EICC moves in the opposite direction from the southwestern Bay, its influence decreasing northwards (Shankar et al. 1996). Flood discharges from peninsular rivers is much smaller ca. 10,000 (annual mean: 3,300) $\mathrm{m}^{3} \mathrm{~s}^{-1}$ for Godavari and $5000(2150) \mathrm{m}^{3} \mathrm{~s}^{-1}$ for Krishna rivers and does not seem to dilute this component. The influence of these rivers may have been confined to near coastal region ( $<30 \mathrm{~m}$ water column) where sampling was not done in this study. In the absence of significant terrestrial influx that can otherwise cause vertical stratification, the southern region is a region of weak upwelling, as shown in CTD profiles. Surface temperature inversion was noticed at many of the southern region coastal stations, as shown for one station (figure 7). Coastal upwelling has been reported to take place away from river mouths off the southwest coast of India (Murty and Varadachari 1968; Shetye et al. 1991). The nitrate to phosphate mean ratio approaches the Redfield ratio of 16 (Redfield 1958) in the southern region (16.9) from a higher ratio (27.4) in the northern region, indicating better autochthonous conditions in the former region.

\subsection{Fluorophores: ex-situ and in-situ inputs and better north-south discriminators}

The advent of Parafac analysis of EEM spectra (Stedmon et al. 2003) marks a significant 

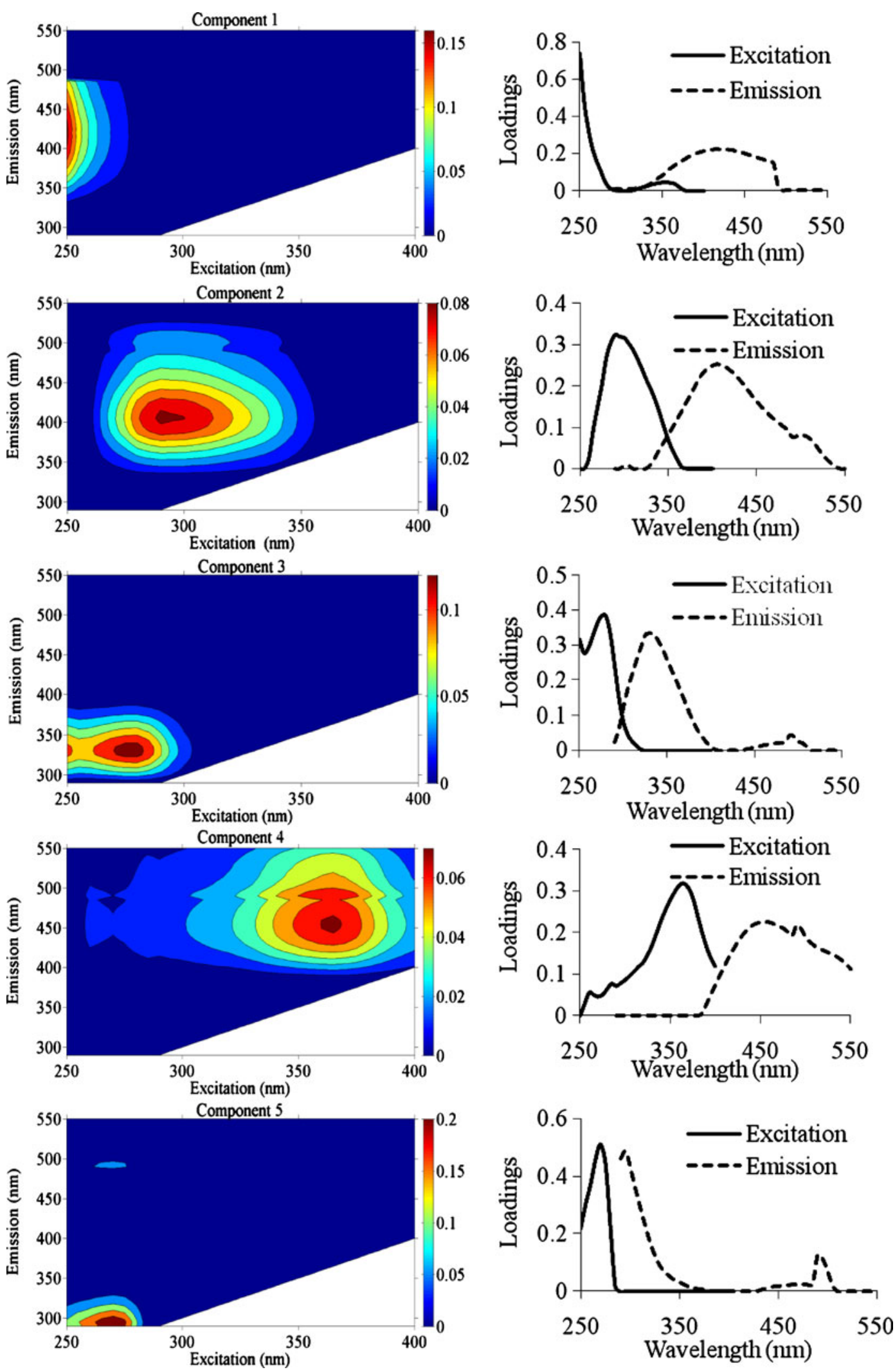

Figure 4. PARAFAC components 1 to 5 and their excitation/emission characteristics.

new development that has facilitated identification and quantification of new fluorophores previously unrecognized due to the problem of overlap of closely occurring fluorophores, and thereby characterize coastal processes (Stedmon et al. 2003; Stedmon and Markager 2005; Luciani et al. 
2008; Murphy et al. 2008; Yamashita et al. 2008; Kowalczuk et al. 2009; Dubnick et al. 2010; Yamashita et al. 2011; Yao et al. 2011). The predominance of A fluorophore in the study area indicates that terrestrial influence is a major factor affecting surface waters of the western Bay of Bengal. We computed the A:C and A:M ratios due to their value as source indicators (Coble 1996). As A fluorophore is distributed between two Parafac components, their total was considered to get the ratios. They were 12.8 and 5.3 for the northern region and 14 and 5.4 for the southern region and compare well with the ratios we recently reported (Chari et al. 2012) for a few stations of the western Bay of Bengal during monsoon season.

The decrease of A fluorophore in the southern region $(\Delta \mathrm{A}=0.0125 \mathrm{RU} ; 50 \%)$, conforms to the hydrographic situation of increasing marine influence (salinity). The HIX, an indicator of the extent of humification of organic matter (Zsolnay et al. 1999) was computed. It is the ratio of two areas (H/L) of emission spectrum at $\lambda_{\text {ex }}$ of $255 \mathrm{~nm}$ (254 nm in literature). These two areas were calculated between 300 and $345 \mathrm{~nm}$ for $\mathrm{L}$ and between 435 and $480 \mathrm{~nm}$ for $\mathrm{H}$. Increased humification of organic material is expected to make the organic material more stable to degradation. The HIX (table 2$)$ is higher in the northern region $(\Delta \mathrm{HIX}=$ $0.36,32 \%)$, and its DOM is inferred as more of riverine character than the southern region.

Among the protein fluorophores, the $\mathrm{T}$ fluorophore which is attributed to phytoplankton production in natural aquatic environment (Coble et al. 1990, 1998) is also higher in the northern region (table 2). But the increase is not as much $(\Delta \mathrm{T}=0.001 \mathrm{RU}, 8 \%)$ as the increase in $\operatorname{chl} a$ equivalent concentration $(\Delta \operatorname{chl} a$ equivalent $=$ $0.99,72 \%$ ) would predict. The fact that B fluorophore, which is also of phytoplanktonic origin

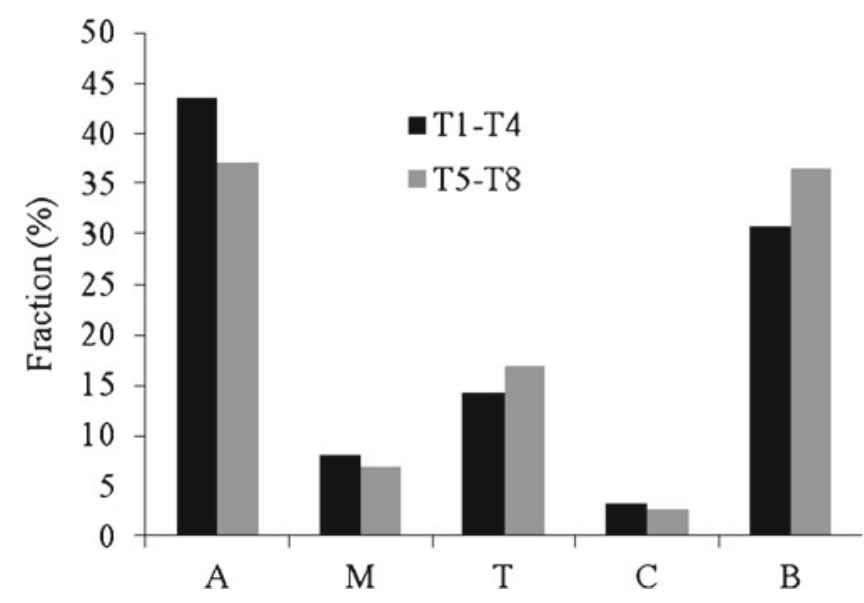

Figure 5. Mean fraction of fluorophores in the northern transects $(\mathrm{T} 1-\mathrm{T} 4)+\mathrm{T} 5(100,200 \mathrm{~m}$ isobaths $)$ and southern transects $(\mathrm{T} 5-\mathrm{T} 8)+\mathrm{T} 5(30,50 \mathrm{~m}$ isobaths $)$.

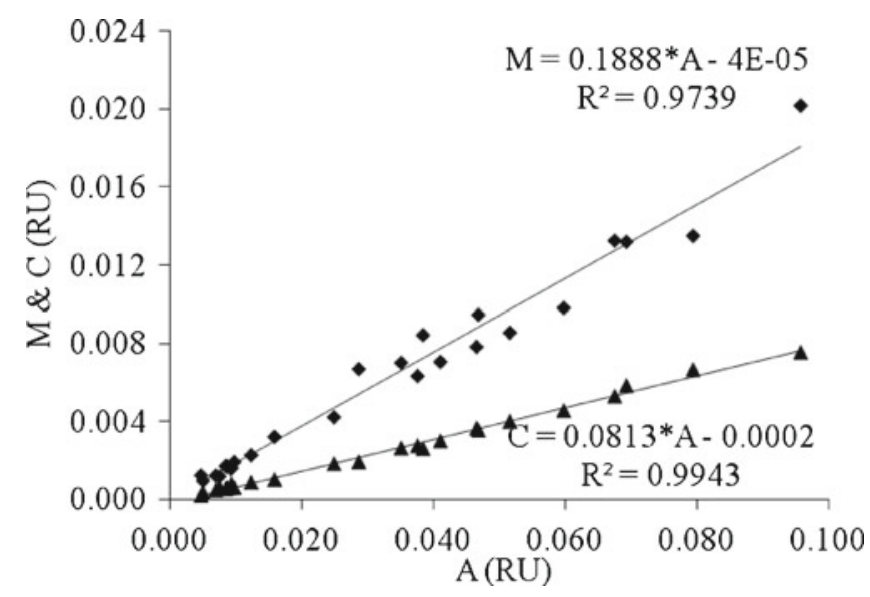

Figure 6. Relationships among A, M and C fluorophores in the two regions.

is significantly higher in the southern region, and not lower adds to the uniqueness of the study area. The freshly formed proteins have a coiled tertiary structure, and in them, tryptophan fluorescence alone is seen (northern region) as the fluorescence energy of tyrosine, is efficiently transferred to tryptophan by the fluorescence resonance energy transfer (FRET) mechanism (Lakowicz 1999). In degraded proteins (southern region), due to the linear structures, tyrosine residues are exposed directly to the medium and the tyrosine fluorescence is also seen (Mayer et al. 1999). Thus whenever the B fluorophore is noticed, protein degradation via bacterial metabolism is inferred (Determann et al. 1996; Coble et al. 1998; Fellman et al. 2010). The B fluorophore is particularly enriched at a few (one or two) stations of the

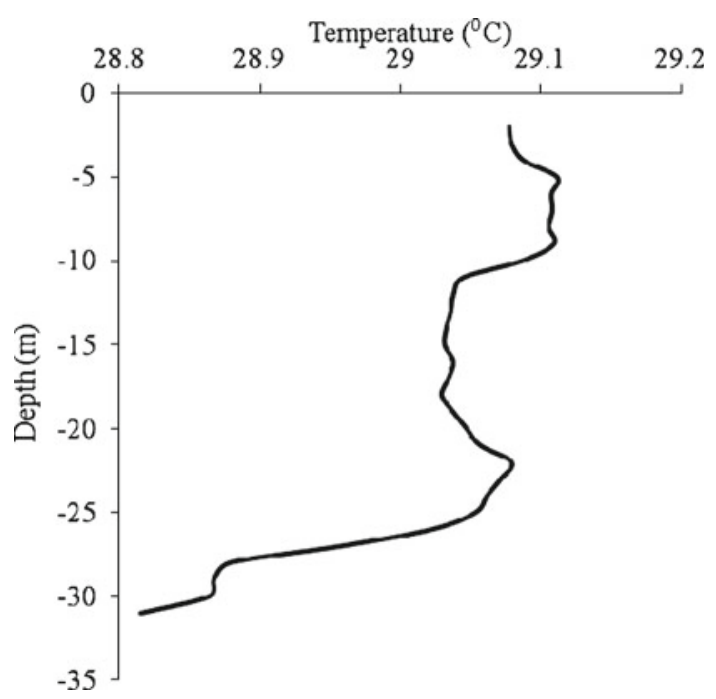

Figure 7. Temperature profile at $30 \mathrm{~m}$ isobath station of T5 transect. 
southern transects, in which dissolved oxygen is lower. It is well known that upwelling does occur in the western Bay of Bengal during southwest monsoon locally (Shetye et al. 1991) that might have brought the protein degradation products surviving bacterial metabolism to the surface.

The new nutrients introduced by upwelling should promote new biological production. As an indicator of recent phytoplankton production, BIX (Huguet et al. 2009) has been computed. The BIX was higher in the southern than the northern region (table $2 ; \Delta \mathrm{BIX}=0.062,7.3 \%$ ) despite its lower chl $a$ equivalent than the latter. This infers that phytoplankton production is indeed greater in the southern region and that its (chl $a$ equivalent's) lower abundance may be due to effective grazing. A southward increase of zooplankton abundance in the western Bay of Bengal has been documented (Nair et al. 1981), and held likely responsible. Lower chl $a$ equivalent of the southern region could also have been due to lower chl $a$ containing phytoplankton, e.g., picoplankton or dinoflagellates. But in time series observations during 2009-2012 (our unpublished results), we did not find dinoflagellates in significant numbers in the monsoon season in the western Bay of Bengal. Thus, fluorescence properties are more informative about phytoplankton production than chlorophyll $a$.

\section{Acknowledgements}

Authors thank Dr Shailesh Nayak, Secretary, Ministry of Earth Sciences (MoES), New Delhi for encouragement, and Dr T Srinivasa Kumar and Dr A A Lotlikar of the INCOIS, Hyderabad for advice and timely support. The authors also thank the Director, CMLRE (MoES, Kochi) for the Vessel and its crew members for cooperation during sample collection. The authors record their appreciation for the helpful criticism of earlier versions by anonymous reviewers and Editor because of which the manuscript improved significantly. The research is part of the SATCORE project No. INCOIS/093/2007, and the authors gratefully acknowledge the Director, INCOIS for financial assistance. Further financial assistance from CSIR, New Delhi in the form of Senior Research Fellow (to NVHKC) and Emeritus Scientist (to NSS) is also thankfully acknowledged.

\section{References}

Anderson C M and Bro R 2003 Practical aspects of PARAFAC modelling of fluorescence excitation-emission data; J. Chemometr. 17 200-215.

Aucour A M, France-Lanord C, Pedoja K, PiersonWickmann A C and Sheppard S M F 2006 Fluxes and sources of particulate organic carbon in the GangaBrahmaputra river system; Global Biogeochem. Cycles 20 GB2006.

Benner R 2002 Chemical composition and reactivity; In: Biogeochemistry of marine dissolved organic matter, Academic Press, pp. 59-90.

Bro R 1997 PARAFAC: Tutorial and applications; Chemometr. Intel. l Lab Syst. 38 149-171.

Carritt D and Carpenter J 1966 Comparison and evaluation of currently employed modifications of the Winkler method for determining dissolved oxygen in seawater; J. Marine Res. 24 286-318.

Chari N, Sarma N S, Pandi S R and Murthy K N 2012 Seasonal and spatial constraints of fluorophores in the midwestern Bay of Bengal by PARAFAC analysis of excitation emission matrix spectra; Estuarine Coast. Shelf. Sci. 100 162-171.

Coble P G 1996 Characterization of marine and terrestrial DOM in seawater using excitation emission matrix spectroscopy; Marine Chem. 51 325-346.

Coble P G 2007 Marine optical biogeochemistry: The chemistry of ocean color; Chem. Rev. 107 402-418.

Coble P G, Green S A, Blough N V and Gagosian R B 1990 Characterization of dissolved organic matter in the Black Sea by fluorescence spectroscopy; Nature 348 432-435.

Coble P G, Del Castillo C E and Avril B 1998 Distribution and optical properties of CDOM in the Arabian Sea during the 1995 southwest monsoon; Deep-Sea Res. II 45 2195-2223.

Del Castillo C E, Coble P G, Morell J M, López J M and Corredor J E 1999 Analysis of the optical properties of the Orinoco River plume by absorption and fluorescence spectroscopy; Marine Chem. 66 35-51.

Determann S, Reuter R and Willkomm R 1996 Fluorescent matter in the eastern Atlantic Ocean, Part 2: Vertical profiles and relation to water masses; Deep-Sea Res. I 43 345-360.

Dubnick A, Barker J, Sharp M, Wadham J, Lis G, Telling J, Fitzsimons S and Jackson M 2010 Characterization of dissolved organic matter (DOM) from glacial environments using total fluorescence spectroscopy and parallel factor analysis; Ann. Glaciol. 51 111-122.

Fellman J B, Hood E and Spencer R G M 2010 Fluorescence spectroscopy opens new windows into dissolved organic matter dynamics in freshwater ecosystems: A review; Limnol. Oceanogr. 55 2452-2462.

Grasshoff K, Ehrhardt M, Kremling K and Almgren T 1999 Methods of seawater analysis; Verlag Chemie, Weinheim, Germany, 398p.

Guéguen C, Guo L and Tanaka N 2005 Distributions and characteristics of colored dissolved organic matter in the western Arctic Ocean; Cont. Shelf. Res. 25 11951207.

Hansell D A and Carlson C A 2002 Biogeochemistry of marine dissolved organic matter; Academic Press, 774p.

Hong H, Wu J, Shang S and Hu C 2005 Absorption and fluorescence of chromophoric dissolved organic matter in the Pearl River Estuary, South China; Marine Chem. 97 78-89.

Hudson N, Baker A and Reynolds D 2007 Fluorescence analysis of dissolved organic matter in natural, waste and polluted waters - A review; River Res. Appl. 23 631-649.

Huguet A, Vacher L, Relexans S, Saubusse S, Froidefond J and Parlanti E 2009 Properties of fluorescent dissolved organic matter in the Gironde Estuary; Org. Geochem. 40 706-719.

Jeffrey S W and Humphrey G F 1975 New spectrophotometric equations for determining chlorophylls $a, b, c 1$ and 
$c 2$ in higher plants, algae and natural phytoplankton; Biochem. Physiol. Pflanz. 167 191-194.

Jian J, Webster P J and Hoyos C D 2009 Large-scale controls on Ganga and Brahmaputra river discharge on intraseasonal and seasonal time-scales; J. Roy. Meteor. Soc. $135353-370$.

Kalle K 1949 Fluoreszenz und Gelbstoff in Bottnischen und Finnischen Meerbusen; Deutsche Hydr. Zeits. 2117.

Kowalczuk P, Cooper W J, Whitehead R F, Durako M J and Sheldon W 2003 Characterization of CDOM in an organic-rich river and surrounding coastal ocean in the South Atlantic Bight; Aquatic Sci. 65 384-401.

Kowalczuk P, Ston-Egiert J, Cooper W J, Whitehead R F and Durako M J 2005 Characterization of chromophoric dissolved organic matter (CDOM) in the Baltic Sea by excitation emission matrix fluorescence spectroscopy; Marine Chem. 96 273-292.

Kowalczuk P, Durako M J, Young H, Kahn A E, Cooper W J and Gonsior M 2009 Characterization of dissolved organic matter fluorescence in the South Atlantic Bight with use of PARAFAC model: Interannual variability; Marine Chem. 113 182-196.

Kowalczuk P, Cooper W J, Durako M J, Kahn A E, Gonsior M and Young H 2010 Characterization of dissolved organic matter fluorescence in the South Atlantic Bight with use of PARAFAC model: Relationships between fluorescence and its components, absorption coefficients and organic carbon concentrations; Marine Chem. 118 22-36.

Lakowicz J R 1999 Principles of fluorescence spectroscopy, 2nd edn, Kluwer, Academic/Plenum Publishers, New York, NY, 725p.

Luciani X, Mounier S, Paraquetti H H M, Redon R, Lucas Y, Bois A, Lacerda L D, Raynaud M and Ripert M 2008 Tracing of dissolved organic matter from the SEPETIBA Bay (Brazil) by PARAFAC analysis of total luminescence matrices; Marine Environ. Res. 65 $148-157$.

Marhaba T F, Van D and Lippincott R L 2000 Rapid identification of dissolved organic matter fractions in water by spectral fluorescent signatures; Water Res. 34 3543-3550.

Mayer L M, Schick L L and Loder III T C 1999 Dissolved protein fluorescence in two Maine estuaries; Marine Chem. 64 171-179.

Murphy K R, Stedmon C A, Waite T D and Ruiz G M 2008 Distinguishing between terrestrial and autochthonous organic matter sources in marine environments using fluorescence spectroscopy; Marine Chem. 108 40-58.

Murty C and Varadachari V 1968 Upwelling along the east coast of India; Bull. Nat. Inst. Sci. India 38 80-86.

Nair S R, Nair V R, Achuthankutty C $T$ and Madhupratap M 1981 Zooplankton composition and diversity in western Bay of Bengal; J. Plankton Res. 3 493-508.

Parlanti E, Wörz K, Geoffroy L and Lamotte M 2000 Dissolved organic matter fluorescence spectroscopy as a tool to estimate biological activity in a coastal zone submitted to anthropogenic inputs; Org. Geochem. 31 1765-1781.

Redfield A C 1958 The biological control of chemical factors in the environment; Am. Sci. 46205.

Sarin M, Sudheer A and Balakrishna K 2002 Significance of riverine carbon transport: A case study of a large tropical river, Godavari (India); Sci. China Ser. C: Life Sci. (English edn) 45 97-108.

Sarma N S, Nageswara Rao I and Annapurna K 1994 Ammonium ion and organic phosphorus as major in situ contributors to dissolved fluorescence of the near northwestern Bay of Bengal; Marine Chem. 47 255-267.

Shankar D, McCreary J P, Han W and Shetye S R 1996 Dynamics of the East India coastal current. 1. Analytic solutions forced by interior Ekman pumping and local alongshore winds; J. Geophys. Res. 101 $13,975-13,991$.

Shetye S, Shenoi S, Gouveia A, Michael G, Sundar D and Nampoothiri G 1991 Wind-driven coastal upwelling along the western boundary of the Bay of Bengal during the southwest monsoon; Cont. Shelf Res. 11 1397-1408.

Stedmon C A and Markager S 2005 Resolving the variability in dissolved organic matter fluorescence in a temperate estuary and its catchment using PARAFAC analysis; Limnol. Oceanogr. 50 686-697.

Stedmon C A and Bro R 2008 Characterizing dissolved organic matter fluorescence with parallel factor analysis: A tutorial; Limnol. Oceanogr. Methods. 6 1-6.

Stedmon C A, Markager S and Bro R 2003 Tracing dissolved organic matter in aquatic environments using a new approach to fluorescence spectroscopy; Marine Chem. 82 $239-254$

Subramanian V 1993 Sediment load of Indian rivers; Curr. Sci. 64 928-930.

Yamashita Y and Tanoue E 2003 Chemical characterization of protein-like fluorophores in DOM in relation to aromatic amino acids; Marine Chem. 82 255-271.

Yamashita Y and Tanoue E 2004 In situ production of chromophoric dissolved organic matter in coastal environments; Geophys. Res. Lett. 31 L14302.

Yamashita Y, Jaffé R, Maie N and Tanoue E 2008 Assessing the dynamics of dissolved organic matter (DOM) in coastal environments by excitation emission matrix fluorescence and parallel factor analysis (EEM-PARAFAC); Limnol. Oceanogr. 53 1900-1908.

Yamashita Y, Panton A, Mahaffey C and Jaffé R 2011 Assessing the spatial and temporal variability of dissolved organic matter in Liverpool Bay using excitation emission matrix fluorescence and parallel factor analysis; Ocean Dyn. 61 569-579.

Yao X, Zhang Y, Zhu G, Qin B, Feng L, Cai L and Gao G 2011 Resolving the variability of CDOM fluorescence to differentiate the sources and fate of DOM in Lake Taihu and its tributaries; Chemosphere 82 145-155.

Zsolnay A, Baigar E, Jimenez M, Steinweg B and Saccomandi F 1999 Differentiating with fluorescence spectroscopy the sources of dissolved organic matter in soils subjected to drying; Chemosphere 38 45-50. 